\title{
"The Messianic Dimensions of Kingship in Deuteronomy 17:14-20 as fulfilled by Jesus in Matthew"
}

Robin Gallaher Branch

(North-West University)

\section{ABSTRACT}

\section{“The Messianic Dimensions of Kingship in Deuteronomy 17:14- 20 as fulfilled by Jesus in Matthew"}

This article examines a brief statement made by Patrick D Miller in his commentary on Deuteronomy, namely that scholars quite likely have missed the most important Old Testament passage relating to the kind of kingship Jesus manifested in his earthly ministry. Deuteronomy 17:14-20 gives a job description for an upcoming, earthly king; it carries messianic dimensions. Christian scholars, however, primarily have pointed to Isaiah and the messianic passages of the royal psalms to provide indication from the Old Testament that Jesus indeed fulfilled the promises therein of the promised king and the Messiah. Reading like a modern "Position Available" advertisement, the qualifications for kingship in Deuteronomy begin by saying the coming king must be God's choice, an Israelite and not a foreigner; frugal, not prone to displays of wealth and military might; and careful to keep his heart faithful to the Lord. Furthermore, a king's first duty is to write for himself a copy of the law and to read it throughout his life.

The kind of kingship Jesus displayed during his ministry indeed exemplified his personal knowledge and careful following of the law, his total obedience to the law, his reverence for the law, and his humility before his disciples - all qualifications for earthly kingship "advertised" in the pericope. The Gospel of Matthew resonates with passages showing that Jesus answered the advertisement, met the job description, and fulfilled the qualifications for kingship outlined prophetically by Moses in Deuteronomy.

\section{INTRODUCTION}

Patrick D Miller (1990:149) in his commentary on Deuteronomy in the Interpretation series concludes his section on the guidelines for a king given in Deuteronomy 17:14-20 with the following comment:

"Much has been written about the way the messianic passages of the royal psalms and Isaiah point us to and 
find their actuality in Jesus of Nazareth. It is possible we have overlooked the text that may resonate most with the kingship he manifested; he was one who sought and received none of the perquisites of kingship, who gave his full and undivided allegiance to God, and who lived his whole life by the instruction, the torah, of the Lord".

Examination of Miller's comment involves taking an inter-textual approach $^{1}$. This paper looks at Miller's statement in relation to the Gospel of Matthew ${ }^{2}$. It first briefly considers the structure of

1 An inter-textual approach is not uncommon. For example, Craigie (1983:64) sees Psalm 2 as a coronation of a Davidic king as do Rogerson and McKay (1977:19). Inter-textual insights on Luke 1 are found by Sobosan (1974:317-323). Smith (ND:642-653 and 792-802) takes an intertextual approach to Isaiah 7-9:8 and the concept of king and messiah. Harstine (2002:40-95) sees Moses as a character in the fourth gospel and in the Synoptic gospels.

2 Issues of dating and authorship of Deuteronomy and Matthew are beyond the scope of this paper. In terms of a date for Deuteronomy, Miller (1990:147) argues that the final version of the text, in this case Deut. 17:1420 , the verses about a king, favours a process of redaction; the final version reflects not so much a prophetic word as a guideline for a king that is tempered by historical reflection, perspective and experience. Hamilton (1982:430), on the other hand, takes a more conservative, traditional view by siding with the original authorship of Moses. Moses "had ample opportunities both inside and outside Egypt to observe the theatrics of oriental despots who revelled in their lifestyles", Hamilton (1982:430) writes. Nelson (2002:8) argues that Deuteronomy was written "as a covert undertaking by dissident Jerusalem scribal circles during the reign of Manasseh and the minority of Josiah" and was done in collaboration with "aristocratic families, elements of the priesthood, and those schooled in wisdom". Nelson (2002:223), noting the "guarded opinion" of the passage regarding the king, adds that the text gives the impression of being written from "grim experience". Hamilton (1998:232-233) believes this portion of Deuteronomy reflects the political and intellectual currents of the Near East during the eight and seventh centuries BCE.

In terms of Matthew, Blomberg (1992:41) says, "The Gospel of Matthew as we know it was almost certainly written before A.D. 100". Hagner (1993:lxxiii) writes that two key questions pertain to the dating of Matthew, namely (1) whether the relationship between church and synagogue indicates that the final break, usually dated around 85 or $90 \mathrm{CE}$ already had happened, and (2) whether the fall of Jerusalem in $70 \mathrm{CE}$ already had 
Deuteronomy 17:14-20 and then that of the Gospel of Matthew. The paper's format then follows the "job description", to use modern parlance, for Deuteronomy's king, and sees how it finds "actuality in Jesus of Nazareth," as portrayed in Matthew". Miller's comment invites looking at Deuteronomy and Matthew in their revelationhistorical aspects. This article employs canonical criticism ${ }^{4}$. It follows B.S. Childs (1985:6-15) in viewing the text via canonical methodology ${ }^{5}$. J P Fokkelman (1975:8) correctly advises interpreters

happened. Hagner (1993: lxxiv), in a very cautionary way, goes sides with a pre-CE 70 date.

3 I am grateful for observations on organization for this article to two professors at Potchefstroom University for Christian Higher Education in Potchefstroom, South Africa; they are Prof Fika J van Rensburg, director, School of Biblical Studies and Bible Languages, and Prof Herrie van Rooy, professor of Old Testament.

4 This article sees Deuteronomy as a foundational text, beloved and believed by those who practice the Jewish faith; this article also acknowledges Deuteronomy and Matthew as foundational texts, beloved and believed by those who practice the Christian faith. Along these lines, Hayes and Holladay (1987:122) note that canonical criticism sees the books of the Bible as foundational texts reflecting and embodying the essence of faith and practice of a believing community. They (1987:123) stress the cohesiveness of the canon and note a canonical approach is synchronic and text-reader oriented. This article uses this model and stresses the interrelationship of Deuteronomy and Matthew. The canonical process loosens the texts from specific historical settings and transcends the original address of the text (1987:124). Canonical criticism assumes the canon's internal cohesion; consequently, even a passage from the Old Testament can be read and heard in light of the New Testament (Hays \& Holladay, 1987:125). Furthermore, the content of one book (in this case Deuteronomy) may connect with the content of another (in this case Matthew) (Hays \& Holladay, 1987:127). Hays \& Holladay (1987:128) add that an interpreter who employs a canonical interpretation "focuses not on the original authorial intention or the circumstances of the original situation but on how the text in its present form and construal bears the theological witness to faith and the gospel".

5 Childs (1985:11-15) likewise offers several tenets of the canonical approach. In the first place it allows one to reflect theologically on the text as it has been received and shaped. Second, the final form of canonical literature, which we call the Bible, reflects a very long history and process of development that is marked and shaped by hundreds of unrecorded decisions. Third, the canonical approach sees the discipline of theology as combining both descriptive and constructive features. In other words, it 
to approach texts like Matthew and Deuteronomy carefully but with an attitude of confidence, expecting to find within the texts themselves keys to understanding.

\section{STRUCTURE OF DEUTERONOMY 17:14-20}

The biblical text consistently affirms that God reserves for himself the right of choosing kings and prophets and of raising up judges (Dt 17:14-20; 18:18; Jdg 3:15). Deuteronomy 17:15 gives "firm yet emphatic permission" to Israel to have a king (Miller 1990:147). Yahweh's act of choosing a king serves as legitimising him (Nelson 2002:222). The text stipulates that the king must be an Israelite ${ }^{6}$ and not a foreigner ${ }^{7}$.

affirms the descriptive task of correctly interpreting the part of the text under consideration by acknowledging the text's place in Israel's faith, and it likewise understands that theological investigation also means the modern interpreter must take a stand regarding the text. Fourth, an interpreter taking a canonical approach acknowledges its flexibility; a canonical approach refrains from looking for a "single key" or a "missing link" that works for all biblical genres in interpretation. Fifth, a canonical approach acknowledges that the texts became what we call scripture within the community of faith. Sixth, the canonical theologian accepts the canon as normative in the life of the Christian community. Finally, the theologian who favours a canonical approach acknowledges his or her need of illumination through the Holy Spirit for both the understanding of a text and its application. This article endorses the six tenets Childs outlines.

6 Deuteronomy 17:14-20 may have been a guideline for the US Constitution. Article II of the US Constitution states that "no person except a natural born citizen, or a citizen of the United States, at the time of the adoption of this Constitution, shall be eligible to the office of President". By joint agreement of the delegates to the Constitutional Convention in Philadelphia, Pennsylvania, in 1776, no records were kept of the deliberations or arguments that went on concerning the writing of the US Constitution. However, these passages on the king in Deuteronomy and president of the United States bear the similarity that each must be a member of the community and not a foreigner. Perhaps the Framers considered Deuteronomy in their deliberations.

7 The phrase in Deuteronomy 17:15, "not a foreigner", is puzzling, especially because the text records no indication that the Israelites ever sought a foreign king. A brief explanation offers insights. The first kings of Israel, Saul and David, definitely were God's choice and from the covenant tribes of Benjamin and Judah respectively (see 1 Sam. 9 \&16). However, Abimelech precedes Saul and David as king (Jdg 8:29-9:57). Abimelech, son of Jeub-Baal (Gideon) and a concubine from Shechem, slaughters his 70 
Surprisingly, Deuteronomy 17:14-20 describes kingship via prohibitions. The text concentrates on what a king ought not to do; in this way it speaks against oriental despots and outside religious sources (Miller 1990:147-148). Curtailed first is the human tendency of greed: the text forbids multiplication of wealth, women, and horses, a symbol of military might ${ }^{9}$. Note, however, that military forces, wives, and a royal coffer are not entirely forbidden but only limited (Nelson 2002:222) ${ }^{10}$.

The king's primary duty is so surprising, seemingly simple, and definitely unusual that it produces an incredulous smile. A king must write for himself a copy of the law! Miller (1990:148) puts it this way: the king's one positive responsibility is to have with him at all times a copy of the law, probably the Deuteronomic law ${ }^{11}$. The

brothers, the natural sons of Gideon and his wives. The concubine is a Canaanite, one outside the covenant (Daube 1971:480). The citizens of his mother's hometown proclaim him king (Jdg 9:1-6) - but a king in a Canaanite fashion (Daube 1971:480). In contrast to the other 12 judges, the text gives no indication that the Lord raises up Abimelech (see Jdg 3:15; $4: 4 ; 13: 5$ ). The text condemns Abimelech because the townspeople elevate him without divine sanction (Daube 1971:480). Abimelech himself and his "reign" never receive divine approval.

8 Deuteronomy 17:14-20 offers a substitute vision of kingship and is placed within the context of religious demands (M V Hamilton 1998:235237.

9 Deuteronomy sets up roadblocks for a king bent on accumulation. Indeed, a king sensitive to the demands of the passage must know he lives constantly in extreme peril because of the ever-present possibilities of being tempted by women, wealth, and military grandeur (V P Hamilton, 1982:430431). Why is this? Perhaps it is because accumulating women, horses, and wealth leads to pride. The natural progression of pride leads to a loss of trust in the Lord and then to unfaithfulness and apostasy (Miller 1990:148).

10 Scholars like Nelson who favour a late date for Deuteronomy maintain this section of Deuteronomy serves as a polemic against the excesses of Solomon's reign. Solomon, for example, had 700 wives and 300

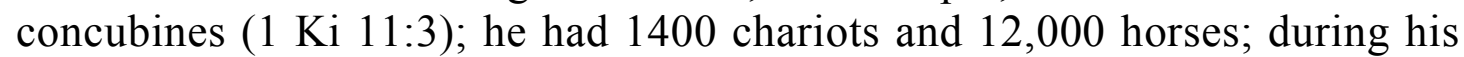
reign he made silver as common in Jerusalem as stones and cedar as plentiful as sycamore-fig trees (1 Ki 10:26-27).

11 Nelson (2002:225) and Driver (1925:212) agree that this verse refers to a copy of the deuteronomic law. Driver (1925:212) adds that the deuteronomic law indicated a standard copy, cared for and in the custody of the Levitical priests in the central sanctuary. V P Hamilton (1982:431) 
king must actively engage in writing for himself a copy of the law, talking about it constantly with his subjects and the Levitical priests who direct his study, and following its instruction diligently (Miller 1990:148) $)^{12}$.

The reason the king must read the law constantly is to learn to fear of the Lord ${ }^{13}$. Fearing God or reverencing God means knowing $\operatorname{God}^{14}$. Fearing God also involves a healthy dose of respecting a supernatural power bigger than oneself! ${ }^{15}$ Because the king must read the law all the days of his life, repetition quite likely leads to memorization, memorization to internalisation, internalisation to obedience, and obedience to teaching others to fear God and serve $\operatorname{him}^{16}$.

Amazingly, the goal of being king is not self-exaltation but its opposite: humility. Although a king is set over his people, his heart

argues that the law may be the whole of Deuteronomy, portions of it, or only Exodus 20-24. Nelson (2002:225) observes that Deuteronomy sees itself as a self-contained entity, a book so important it became a protocanonical book, and a legal document to which even a king is subject. However, "the law" also could refer to the Pentateuch. This article favors the latter view, namely that "the law" refers to the Pentateuch. It would seem logical that the king would need to know the history of Israel, the covenants, and various community and cultic laws in order to govern God's people Israel.

12 The Hebrew verb, qatab, is in the regular qal verb state and not in hitpael, the reflexive model used when a person does something like dress himself. Nonetheless, Nelson (2002:223) opts for a reading emphasizing that the king writes out the law for himself.

13 This is a positive formulation of the first commandment (Miller 1990:148), and a safeguard against apostasy and idolatry.

14 God hearkens to those who fear, revere, and hold his name in awe (see Ps 33:18).

15 Acknowledging fear and addressing fear are two of the hallmarks of a theophany in the Old Testament. In the Bible, fear can mean anxious dread or terror when confronting danger or reverence and awe of God (Jolley 2000:457). Prophets addressed their hearers with these words, "Fear not" (see $1 \mathrm{Ki}$ 17:13); Moses tells the Israelites not to be afraid (see Dt 1:29); God tells Joshua not to be afraid (Jos 1:9). angelic messengers tell human beings not to fear (see Dt 10:12,19). Jesus follows this divine tradition.

16 The command in Deuteronomy that the king not turn from the law to the right or to the left is repeated in the Book of Joshua first by the Lord $(1: 7)$ and next by Joshua himself as his farewell address to the leaders of Israel (23:6). 
may not be haughty and he may not think of himself as superior to his brothers (Miller 1990:147) ${ }^{17}$. Israel's ideal king rules with a bag full of the law! He is more a student on foot carrying books than a ruler being driven around by a slave in a chariot. He's "the people's king" - accessible, "a regular Joe", the boy next door, a good neighbour. If anything, this king would rather take the back seat than sit at the head table. This king doesn't introduce himself as king. This king doesn't make people bow before him. Instead as an ideal Israelite, he introduces people to the real king of Israel, Yahweh. Because he reads the law constantly, he is not self-important or haughty.

Significantly, Deuteronomy omits from its job description elements history records as a successful king's essential qualities. The text says nothing about a standard role of kingship: military leadership, or about another taken-for-granted aspect of kingship: administrative ability, or about the showmanship necessary for ruling: ceremonial responsibilities.

In summary, Deuteronomy 17:14-20 tersely presents a model of character for a true Israelite (Miller 1990:147). The passage stresses a careful, consistent, lifelong obedience to one thing: the divine law (Miller 1990:148). The king must pass on this singlemindedness to his descendants in order that they might live ${ }^{18}$. In an interesting sidenote, V P Hamilton (1982:431) suggests this text's structure resembles the rules of worship in Deuteronomy 12, possibly indicating the king leads the people in worshiping the Lord.

17 In addition, the king must not take the place of God in the lives of the people; furthermore, a king who usurps his role becomes a tyrant (see Miller 1990:148).

18 Deuteronomy 17:14-20, however, contains similarities with treaties and negotiations in the ancient Near East. For example, the suzerain, the most powerful monarch or lord in the region, exercised authority over the king of a vassal (Thompson 1974:205). God as king over Israel rules over Israel's king. Yet another parallel with treaties in the ancient Near East is that a duplicate treaty - like a copy of the law - was to be held by the vassal king and read publicly on a periodic basis (Thompson 1974:206). The Levitical priests had a copy, too, and kept it in the central sanctuary (Thompson 1974:206). 


\section{STRUCTURE OF MATTHEW}

Matthew arguably structures his gospel around the theme of kingship. The gospel begins with a genealogy of the lineage of Jesus. It is a kingly lineage. Significantly, the Gospel's 28 chapters contain an inclusio, gentiles who acknowledge Jesus as king. First, the magi come looking for the King of the Jews (Mt 2:2), and second, Pilate asks Jesus if he is the king of the Jews (Mt 27:11); hours later the inscription, "This is Jesus, the King of the Jews," is placed above Jesus' head on the cross (Mt 27:37). The chapters between this inclusio give evidence of, among other things, aspects of Jesus as king. Throughout the Gospel, Matthew consistently presents Jesus as king (Mt 1:1;2:2;20:25-28;27:11) ${ }^{19}$, Christ (16:16), and fulfiller of the law (Mt 3:15).

\subsection{Lineage}

The Gospel of Matthew opens by immediately giving Jesus the messianic, kingly appositive, "son of David," and the covenant appositive, "son of Abraham" (Mt 1:1). Matthew's kingly lineage $(1: 1-17)$ presents in truncated form three groups of 14 generations ${ }^{20}$. These 42 generations go back to Abraham ${ }^{21}$. The theme of Matthew's genealogy is the fulfilment of scripture (Blomberg 1992:52). The genealogy contains the historical and legal basis for showing that the Gospel's subsequent chapters amply provide

19 There is, however, no direct mention in Matthew of Deuteronomy 17:14-20. A basic hermeneutical principle applies, nonetheless, namely that of letting scripture interpret scripture. Often what is mentioned in one part of the Bible (in this case Deuteronomy) is elaborated on, clarified, or expanded in another part of scripture, in this case Matthew (Kaiser \& Silva 1994:199200). As is common throughout the biblical text, words and deeds tell character more so than does an editorial comment (Kaiser \& Silva 1994:7374).

20 The number 14 also may be the numerical value (by gematria) of DWD (4-6-4), the Hebrew letters of David's name (Hill 1972:74). Another interesting point about the genealogy is that "son of Perez" is a rabbinic name and title for the Messiah (Hill 1972:74).

21 In contrast, the Lukan genealogy follows Jesus' lineage from Adam (Cox 1968:28). Two other possibilities emerge in a comparison of the genealogies (NIV 1995:1541, note on Lk 3:23-38). First, Matthew traces the legal descent of David's house while Luke shows the line of Joseph to David. Second, Matthew follows the line of Jesus' legal father, Joseph, while Luke emphasizes the line of Jesus' blood relative, Mary. 
evidence that Jesus is the fulfilment of the promises to Abraham and David (Hagner 1993:12). The title "son of David," a favourite of Matthew, occurs 10 times in his gospel as compared to four times each in Luke and Mark; it stresses Matthew's view that Jesus is already the fulfilment of the coming king (Hagner 1993:9). Peter's confession of Jesus as Messiah (Mt 16:16), probably within Jesus' second year of ministry, continues Matthew's emphasis on Jesus as king $^{22}$.

Matthew probably wrote to a Jewish audience ${ }^{23}$. His readers would know all too well that none of the 15 kings listed in the line of David (Mt 1:1-17) fulfilled Deuteronomy's austere requirements. Fulfilling them required a holy life; few kings were so inclined (Thompson 1974:206). 1 and 2 Kings acknowledge seven kings David, Asa, Jehoshaphat, Uzziah, Jotham, Hezekiah, and Josiah - as $\operatorname{good}^{24}$. The remaining eight failed to do right in the eyes of the

22 It is uncertain when the title of Messiah began to be given to the expected, future king (Davidson 1905:123).

23 Matthew's heavy use of the Old Testament reinforces the view that his Gospel serves as an apologetic seeking to convince non-believing Jews of the validity of the claims of Jesus as king, messiah, lawgiver, and judge (Blomberg 1992:34; Cox 1968:22). Scholars speak of the "missionary propaganda" contained in the Gospel of Matthew and argue that one of its major purposes is to show Jesus as Messiah (Hagner 1993:lix). Matthew's stress on Jesus as the fulfilment of existing scripture supports this hypothesis (Hagner 1993:lix).

24 For the narrational verdicts on the reigns of David, Asa, Jehoshaphat, Uzziah (Azariah), Jotham, Hezekiah, and Josiah see 1 Kings 14:8; 15:11; $22: 43$; 2 Kings $15: 3 ; 15: 34 ; 18: 3 ; 22: 2$ respectively. Solomon and Rehoboam receive mixed reviews - but the text leans toward a lifelong evaluation of evil for their lives. Carter (1997:11) argues that Jesus presents Solomon in a negative perspective in Matthew 6:29. In addition, Solomon exploited people in order to get wealth and was preoccupied with his own prestige (Carter 1997:22).

Six kings - Abijah/Abijam (1 Ki 15:3), Jehoram (2 Ki 8:18), Ahaz (2 Ki 16:2), Manasseh (2 Ki 21:2), Amon 2 Ki 21:20) and Jeconia/Jehoiachin (2 Ki 24:9) - receive the epithet of doing evil in the eyes of the Lord. Thompson (1974:206) correctly argues that one of the results of not obeying the commands in Deuteronomy for the kings of Judah was suffering the judgment of the Lord from either the hand of fellow Israelites or from foreigners. 
Lord $^{25}$. However, all failed in some way ${ }^{26}$. Matthew recounts that Herod the Great, King of Judea, Galilee, Iturea, and Traconitis (37-4 BCE) (NIV 1995:1438), further failed to meet the requirements of the job description in Deuteronomy; he didn't know the law (Dt 17:19). Herod needed to ask the scribes where the Christ was to be born (Mt 2:4-6). However, he took seriously the magis' visit to Jerusalem and believed their report regarding the birth of "the king of the Jews" (Mt 2:2). Matthew further confirms Herod's failure as king by showing how he attempted to kill the baby Jesus and succeeded in killing the toddler boys in Bethlehem (Mt 21-18 ${ }^{27}$.

After establishing a lineage in which no king meets Deuteronomy's qualifications and showing that Herod likewise fails $^{28}$, Matthew arguably spends the rest of his gospel giving

252 Chronicles sums up the life of one of the evil kings, Jehoram, in this rather humorous way: "Jehoram was 32 years old when he became king, and he reigned in Jerusalem eight years. He passed away, to no one's regret, and was buried in the city of David, but not in the tombs of kings" (2 Chr 21:20) (italics added).

26 For example, David "multiplied wives"; he had eight wives and 10 concubines (2 Sm 20:3; $1 \mathrm{Chr} 3: 6-8$ ); in addition he committed adultery and murder (2 Sm 12:9). Asa did not remove the high places (2 Ki 15:14). Jehoshaphat also did not remove the high places, and the people continued to offer sacrifices and burn incense there (1 Ki 22:43). Uzziah (Azariah) also did not remove the high places, and the people continued to offer sacrifices and burn incense there ( $2 \mathrm{Ki} \mathrm{15:4).} \mathrm{Jotham} \mathrm{also} \mathrm{did} \mathrm{not} \mathrm{remove} \mathrm{the} \mathrm{high}$ places, and the people continued to offer sacrifices and burn incense there (2 Ki 15:34). Although presented as an exemplary king in 2 Kings, Hezekiah shows a selfishness and a lack of caring for others after him (Is 39:9). Josiah, also an exemplary king ( $2 \mathrm{Ki} 23: 25$ ), walked obediently before the Lord, yet even his obedience did not turn away the Lord's fierce anger against Judah (2 Ki 23:26). Josiah's life presents an interesting case. Jonker (2003:32-33) posits that Pharaoh Neco, a foreign king, knew the will of the God of Israel regarding Judah's foray into war better than did Josiah himself. Josiah ignored Pharaoh Neco's warning and thus precipitated his own death (Jonker 2003:32-33).

27 I am grateful for this insight about the structure of Matthew to Steve Moyise (2003), professor of New Testament at Chichester University.

28 Herod the Great, however, presents a complex picture historically. Records show he was cruel, vindictive, and perhaps even paranoid in his dealings with his family; yet he improved the lot of Jews during his reign 
examples of how Jesus fulfils the directives and "Position Available" description of the king in Deuteronomy.

\subsection{God's choice of Jesus and Jesus' obedience}

The story of Jesus' baptism (Mt 3:13-17) shows not only God's choice of Jesus but also Jesus' obedience. Although Matthew's gospel does not describe Jesus' baptism itself, it does describe what happens immediately afterward ${ }^{29}$. God places his stamp of approval on him in two ways (Blomberg 1992:81). First, the Holy Spirit descends upon Jesus like a dove, suggesting some sort of visible manifestation; and second, a voice from heaven comes saying, "This is my Son, whom I love; with him I am well pleased" (Mt 3:17) ${ }^{30}$. One interpretation of the voice is that divine communication between God and Israel resumes - after several hundred years of silence - with Jesus' baptism (Blomberg 1992:82) ${ }^{31}$. The voice from heaven identifying Jesus contains a startling confluence of two images: the king-messiah of Psalm 2:7, and the servant of the Lord, the one in whom my soul delights of Isaiah 42:1 (Freeman 1993:286-287).

Note two things in the baptismal pericope: first, the ordinary quality of the scene - at least initially, and second, its emphasis on righteousness and obedience. First, Matthew gives no evidence that John knew Jesus intended to come; evidently, Jesus arrives unannounced. Jesus' baptism occurs without any human homage or pomp; recognition instead comes in the form of a sign from heaven and a voice from heaven. Throughout the baptismal scene, gentleness and humility prevail. If others are there likewise presenting themselves for baptism, as a similar account in Luke (3:21) indicates, Jesus blends in with the crowd. He seeks no

(Richardson 2000:580). His chief monument (to himself?) was the rebuilding of the temple in Jerusalem (Richardson 2000:582).

29 Hagner (1993:54) agrees that the events surrounding the baptism rather than the baptism itself form the centre of attention.

30 Freeman $(1993: 286)$ writes that the voice from heaven saying "This is my Son" (Mt 3:17) is the first direct characterization of Jesus in the Gospel of Matthew; furthermore, it foreshadows subsequent confirmations in $\mathrm{Mt}$ 16:16 and 27:54 of Jesus as the Son of God and provides a foundation for them.

31 Moyise (2004), however, notes that the prophetic silence between Malachi and John the Baptist has been generally discredited. 
recognition; Matthew presents him as merely one among many seeking John's ministry, a hidden, humble king.

Second, the baptismal pericope emphasizes righteousness (Mt $3: 15)$; the concept of righteousness occurs seven times in Matthew (Hagner 1993:56) ${ }^{32}$. Righteousness is an attribute of God (Ps 7:9; Is. 41:10). On a human level, righteousness, defined as accomplishing God's will in its fullness, represents a pre-eminent goal of discipleship (Mt 5:20; 6:1, 33) (Hagner 1993:56). By his willingness to be baptized, Jesus indicates his own discipleship to God, a requirement in Deuteronomy. Righteousness also means completing everything that forms a part of a relationship of obedience to God (Blomberg 1992:81). Obedience, also defined as doing the will of God, is a key part of the job description of Deuteronomy's king; in order for his reign to continue and for him to leave a legacy of descendants, he must obey the law and teach others to do so (Dt $17: 20)$.

\subsection{Jesus' knowledge of the law}

Jesus' baptism climaxes with a voice from heaven boldly announcing Jesus as God's son (Mt 3:17). Matthew immediately presents the temptation in the wilderness (Mt 4:1-11) as proof of Jesus' sonship ${ }^{33}$. Does Jesus exhibit qualities called for as God's Son and ideal Israelite - namely trust, obedience, faithfulness (Hagner 1993:61)? Significantly, Matthew's account of the temptation parallels Israel's experience of testing in the wilderness. Jesus answers the tempter's questions from Deuteronomy 8 and 6 respectively, the passage describing Israel's wilderness testing (Hagner 1993:62).

The temptation pericope (Mt 4:1-11) falls into three segments: the temptation to turn stones into bread ( $\mathrm{vv} 3-4)$; the temptation to

32 Jesus acknowledges John's concerns but says, "Let it be so now; it is proper for us to do this to fulfil all righteousness" (Mt 3:15). Griffiths (1951:156) correctly points out that the acts of righteousness also can be translated as salvation.

33 Przybylski (1974:227) places justifiable emphasis on the unity of the baptism and temptation stories. He (1974:225) argues that the temptation pericope serves as a major organizing principle for Matthew and foreshadows what will come. For example, the second temptation foreshadows the transfiguration narrative (Mt 17:1-13), he (1974:227) asserts. 
prove God's care by jumping from a pinnacle of the temple (vv 5-7); and the temptation to believe the tempter's promise of handing over all the kingdoms of the world in exchange for Jesus' promise to worship the tempter ( $\mathrm{vv} 8-10)^{34}$. Jesus responds to each temptation with the formula "It is written" (vv 4, 7 10). Jesus cites Deuteronomy $8: 3 ; 6: 16$; and $6: 13$ in answer to the temptations for immediate food, immediate protection against premeditated folly, and immediate gratification of power ${ }^{35}$.

The idea of the first temptation is this: since you are the Son of God, it is within your power to turn these stones into bread (Hagner 1993:64-65) ${ }^{36}$. Jesus replies within the context of Israel's failure in the wilderness. While Israel failed its testing, Jesus goes through his in victory (Hagner 1993:65). Why? Because he realizes that no man - let alone the Son of God and the King of Israel - can live without the word that comes from the mouth of the Lord (Dt 8:3). Jesus teaches this truth from Deuteronomy in a positive way (Hagner 1993:65-66).

In the second temptation, the tempter takes Jesus to a high pinnacle on the temple. The temple quite likely symbolizes God's presence and protection. From there, the tempter commands Jesus to test God; Jesus must force God to "prove" his love ${ }^{37}$. The tempter

34 Sim (1996:77-78) writes that the temptation episode establishes Satan as the adversary of Jesus. Furthermore, the temptation scene supports the dualism in the Gospel of Matthew; there is no middle ground: it is either the way of God or the way of Satan (Sim 1996:89).

35 The temptation takes place in the context of fasting for 40 days. Moses and Elijah fasted for 40 days and Daniel for three weeks (Ex 24:18; 34:28; Dt 9:9, 18; 1 Ki 19:8; Dn 10:2-3) (Kohlenberger III 1993:157). The biblical text shows no record of a king fasting for a long period of time, but there are instances of fasting on the part of royalty. David fasted for seven days before the death of his unnamed son (2 Sm 12:16-18). Jehoshaphat proclaims a fast for Judah (2 Chr 20:1-4). Esther, her maids, and the Jews of Susa fast for three days (Es 4:16).

36 Matthew 4:3,6 "If you are the son of God" is not a question expressing doubt but more an assumption (Hill 1972:100; Hagner 1993:64). A better translation is this: "Since you are the son of God". Demons and the tempter know intuitively that Jesus is the Son of God.

37 In the second temptation, the devil misquotes Psalm 91 ("lest you stumble/strike your foot against a stone") by encouraging Jesus to commit a premeditated action of hurling himself off a high place (Blomberg 1992:85). 
commands Jesus to throw himself off the temple - an action of sure death unless God intervenes. Jesus replies by quoting scripture. "It is written, Jesus, says, "Do not put the Lord your God to the test"' (Dt 6:16; Mt 4:7). Again, Jesus does not fail God as Israel failed God in the wilderness at Massah (Ex 17; Ps 95:9).

Perhaps the third temptation occurs on Mount Nebo where Moses saw the Promised Land (Dt 34:1-4) (Taylor 2001:30) ${ }^{38}$. There the tempter offers Jesus the kingdoms of the world, their wealth and status, and everything the world has to offer upon the condition that Jesus worship the tempter ${ }^{39}$. This temptation presents the easy way to instant wealth, power, glory - all without the cross. Jesus scoffs, "Get away from me, Satan," and cites Deuteronomy 6:13: "Fear the Lord and serve him". Here again, Jesus' answer shows his trust in his Father and his obedience to his Father's will. Throughout Matthew, Jesus insists on worshipping and serving God alone (Mt $2: 2 ; 8: 2 ; 9: 18 ; 14: 33 ; 15: 25 ; 20: 20 ; 28: 17$ ) (Blomberg 1992:86).

Significantly, Jesus succeeds in his tests. His responses indicate the rightness of his heart (Hagner 1993:69). Jesus refuses the world, its wealth, instant success, and instant acclaim. Jesus refuses to follow other gods - in this case the tempter (Dt 6:14). In these refusals, he chooses obedience; he chooses to love God with all his heart, soul, mind and strength (Dt 6:5). Jesus plainly demonstrates that he loves God more than he loves any temptation. In this he displays Deuteronomy's model of kingly leadership ${ }^{40}$.

By his example, Jesus teaches how wrong it is to put oneself in jeopardy to test God (Blomberg 1992:85).

38 According to tradition in the ancient Near East, a mountain top is seen as a place where the divine presence meets man; it is therefore a place of revelation and worship (Taylor 2001:35). The contrast in this second temptation between Moses and Jesus stands out: Jesus is the new Moses, Matthew emphasizes (Taylor 2001:36).

39 The tempter shows Jesus all the kingdoms of the world, but the dominion offered to him, according to the text, transcends earthly kingdoms; it exceeds the limitations of all earthly power, especially that of Rome (Taylor 2001:37). Furthermore, it exceeds the scope of Jewish thought and Jewish liberation movements of the day; it even exceeds the known scope of David's future messianic kingdom (Taylor 2001:37, 39).

40 Jesus uses the temptation as a teaching vehicle (Cox 1968:38). According to historical tradition, Jesus mediated the temptation story to his disciples; undoubtedly it encouraged them when they confronted their own 


\subsection{Jesus and military matters}

Matthew gives no indication that Jesus organized an army, married, or obtained wealth (Dt 17:16). However, Matthew points out the amazing military force available at Jesus' command. During Jesus' arrest in the Garden of Gethsemane, one of Jesus' companions draws his sword and cuts off the ear of the high priest's servant (Mt 26:51). Jesus responds by ordering the man to put up his sword and saying: "Do you think I cannot call on my Father, and he will at once put at my disposal more than twelve legions of angels?" (Mt 26: 52-53).

If a legion is 6,000 soldiers, then twelve legions could be as many as 72,000 angels (Blomberg 1992:399; Hagner 1995:789). Yet Jesus chooses not to use this military might. Instead he stresses the fulfilment of scripture and reaffirms his obedience to them (Mt 26:54) (Hagner 1995:790). Those closest to him must have been amazed at his restraint, because they knew Jesus frequently mentioned angels. Earlier in Matthew Jesus commands and sends angels (Mt 13:41; 24:31) and says he will come again with angels (Mt 16:27; 25:31) (Hagner 1995:790) . $^{41}$

\subsection{Jesus' careful following of the law}

Another example showing that Jesus quite possibly fulfils the job description of king "advertised" in Deuteronomy is Matthew's emphasis that Jesus adheres to the prophetic heritage (McVann 1993:20 $)^{42}$. In the Sermon on the Mount he says, "Do not think that I

temptations (Hagner 1993:63). Deuteronomy's king teaches his descendants and subjects orally from his knowledge of the law and teaches them by his personal example of following the law.

41 Matthew 13:41 involves the parable of the weeds. Jesus says that the "Son of Man will send out his angels, and they will weed out of his kingdom everything that causes sin and all who do evil". Matthew 24:31 concerns the coming of the Son of Man at the end of the age; at this time the Son of Man "will send his angels with a loud trumpet call, and they will gather his elect from the four winds, from one end of the heavens to the other". Matthew 16:27 also involves the coming of the Son of Man; at an unspecified time "the Son of Man is going to come in his Father's glory with his angels, and then he will reward each person according to what he has done". Matthew 25:31 also speaks of the coming of the Son of Man "in all his glory, and all the angels with him".

42 McVann (1993:20) sees the Gospel of Matthew as the fulfilment of Jesus as Prophet (Dt 18:18) instead of stressing his kingship. 
have come to abolish the Law or the Prophets; I have not come to abolish them but to fulfil them" (Mt 5:17) ${ }^{43}$.

Throughout Matthew, Jesus not only clarifies the law but also constantly raises the standard. Jesus, as God's son as portrayed in

43 Matthew records these incidents that back up Jesus' statement: Mt 1:22 All this took place to fulfil what the Lord had said through the prophet: "The virgin will be with child and will give birth to a son and they will call him Immanuel - which means, God with us".

Matthew 3:15: Jesus replied, Let it be so now; it is proper for us to do this to fulfil all righteousness".

Matthew 4:13-16: Leaving Nazareth, he went and lived in Capernaum, which was by the lake in the area of Zebulun and Naphtali - to fulfil what was said through the prophet Isaiah: Land of Zebulun and land of Naphtali, the way to the sea, along the Jordan, Galilee of the Gentiles - the people living in darkness have seen a great light; those living in the land of the shadow of death, a light has dawned".

Matthew 13:14: In them is fulfilled the prophecy of Isaiah: "You will be ever hearing but never understanding; you will be ever seeing but never perceiving. For this people's hearing has become calloused; they hardly hear with their ears and they have closed their eyes. Otherwise they might see with their eyes, hear with their ears, understand with their hearts, and turn, and I would heal them".

Matthew 13:35: So was fulfilled what was spoken through the prophet: "I will open my mouth in parables, I will utter things hidden since the creation of the world".

Matthew 26:54: Speaking during his arrest Jesus discourages his disciples from fighting back by saying, "But how then would the Scriptures be fulfilled that say it must happen in this way?"

Matthew 26:56: Facing the crowd at his arrest, he chastises them for their cowardice. Why didn't they seize him when he taught in the temple courts? Then he says, "But all this has taken place that the writings of the prophets might be fulfilled".

According to Matthew, Jesus also sought to fulfil the spoken word of the prophets.

Matthew claims Jesus fulfils the words of Isaiah about God's servant, Isaiah 42:1-4 (Mt 12:18-21). Matthew says Jesus is the one Isaiah prophesied would take up our infirmities and carry our diseases (Is 53:4; Mt 8:17). Matthew says that Jesus' triumphal entry into Jerusalem fulfilled the words of the prophet Zecharaiah (9:9): "Say to the Daughter of Zion, See you king comes to you, gentle and riding on a donkey, on a colt, the foal of a donkey" (Mt 21:5). 
Matthew, has the authority to interpret the law (Filson 1960:85). Jesus rejects the rabbinic division of naming 613 laws and dividing them into heavy and light categories (Filson 1960:84). For him, all laws, because they come from God, carry equal weight. In addition, Jesus tolerates no moral slackness; he regards holiness as normal. This new order of Christ-centred law is set forth within the context of divine grace. Jesus makes available the discipline of grace to his hearers (Cox 1968:46).

Matthew 5:21-48, a section of the Beatitudes known as the Six Antitheses, relies heavily on the Old Testament (Hagner 1993:110); the pericope contains five references to Exodus, three to Leviticus, and seven to Deuteronomy. Here Jesus gives an exposition of the true meaning of the Torah (Hagner 1993:111). He sets forth the incomparable ethical demands of kingdom citizenship; he emphasizes that the righteousness of the Pharisees and their interpretation of God's laws must be exceeded (Hagner 1993:111). He surpasses the teaching of the rabbis who preferred to base their instruction not so much on the biblical text as on the views of other teachers (Hagner 1993:111). His formula upgrading the rabbis' teaching - "You have heard it said... But I say to you" - is a messianic formula establishing his identity as the rightful interpreter of the Law of God. "But I say to you" shows he is the Messiah bringing in the Kingdom of God (Hagner 1993:111). Clearly, Jesus in Matthew knows, follows, and teaches the law - all part of Deuteronomy's “Job Description".

\subsection{Humility}

Jesus rarely describes himself, but when he does, his description merits attention ${ }^{44}$. Jesus says this about himself: "Come to me, all you who are weary and burdened, and I will give you rest. Take my yoke upon you and learn from me, for I am gentle and humble in

44 See also God's self-description in Ex 34:6-7: "And he passed in front of Moses, proclaiming, 'The Lord, the Lord, the compassionate and gracious God, slow to anger, abounding in love and faithfulness, maintaining love to thousands, and forgiving wickedness, rebellion and sin. Yet he does not leave the guilty unpunished; he punishes the children and their children for the $\sin$ of the fathers to the third and fourth generation"'. God's selfdescription is born out repeatedly in the biblical text (see Ex. 22:27; Nm 14:18, 20; Pss 61:7; 78:38; 86:15; 103:8; 108:4; 115:1; 138:2; Jnh 4:2; Jr 15:15; 20:7-8; Rm 2:4; Ja 5:11). 
heart, and you will find rest for your souls. For my yoke is easy and my burden is light" (Mt 11:28-30) (italics added).

In this astonishing passage, Jesus calls people first to himself and second to his yoke of discipleship (Hagner 1993:323). The passage closely parallels God's words to Moses, "My Presence will go with you, and I will give you rest" (Ex 33:14). Jesus' call, "Come to me", resembles Lady Wisdom's call to passers-by in Proverbs $(1: 20-33 ; 8: 1-21)^{45}$. Jesus calls people to himself for the purpose of their becoming his disciples. The word yoke here represents the ${ } \mathrm{aw}^{46}$. But Jesus' yoke is not considered burdensome; in this way it parallels Deuteronomy 30:11: the Lord's covenant demands are "not too difficult for you or beyond your reach" (Dt 31:11) (Charette 1992:297).

Note, however, that Jesus' call to take on the yoke of the law is mediated through his teaching and his interpretation of the law, hence the emphasis on "my yoke" (Hagner 1993:324) ${ }^{47}$. In describing himself as meek, Jesus quite likely compares himself to Moses (see Jr 26.6, Zph 3:2, \& Nm 12:3). Jesus is described as humble only in Matthew (Hagner 1993:324) ${ }^{48}$. In this passage, Jesus humbly offers his hearers a choice; yet he honours them by not forcing them to make a choice. Matthew here presents Jesus as the

45 Hagner (1993:323) observes that the command "Come to me" also resembles that spoken by personified Wisdom in Sirach $(24: 19 ; 51: 23)$. But Stanton (1982:5-6) differs, saying that these words spoken by Jesus cannot resemble Sophia in Sirach because she is not meek and lowly.

46 Additional meanings of "yoke" in scripture include the yoke of God and the yoke of heaven (Stanton 1982:8).

47 In this passage, Jesus also contrasts himself with the Pharisees. They load people with heavy burdens; their exegesis of the law involves rigorous requirements. Hagner (1993:325) writes: "The Pharisees build a fence around the Torah with their elaborate and complicated exposition of its meaning, while Jesus goes directly to the heart of the Torah. This difference exists not simply because Jesus is a better exegete of the law than are the Pharisees (as one rabbi among others) but because Jesus is the messianic king and the kingdom has dawned through his deeds and words".

48 Freeman (1993:287) correctly argues that Matthew continues the idea of Jesus as a humble king in other passages. For example, Jesus must humbly suffer (16:21-23); Jesus must humbly submit to being killed (17:22$23)$; and Jesus must humbly submit to betrayal (20:17-19). 
humble yet forceful, kingly, Messianic shepherd who calls to the lost sheep of the house of Israel (Charette 1992:293) ${ }^{49}$.

Humility ties in with a rule in Jesus' new kingdom: service. Jesus says of himself, "The Son of Man did not come to be served, but to serve, and to give his life as a ransom for many" (Mt 20:28) ${ }^{50}$. Servire est regnare (to serve is to reign) is the foundation of the Kingdom of God and Christian ethics (Cox 1968:128; Hagner 1995:582). Greatness, honour, prestige, and standing in God's kingdom become measured by a new standard: that of being a slave. Rewards are not to be pursued or even really thought about unduly. Instead, the present moment of service is of more importance. Disciples, co-equal brothers and sisters, are characterized by humility, servanthood, and even obedience to the death (Hagner 1995:583). The ticket to reigning with Jesus is being like him; quite likely this means sharing his cup of suffering (Hagner 1995:583).

\section{CONCLUSION: THE CRUCIFIED KING ANSWERS THE JOB DESCRIPTION IN DEUTERONOMY}

Throughout Matthew, Jesus upsets the applecart of prevailing kingship and kingdom models. Throughout Matthew, Jesus never denies he is a king and has a kingdom. However. he denies his kingdom runs by the same rules as kingdoms with which John, James, and their mother are familiar (Mt 20:20-28). In Jesus' coming kingdom, service precedes greatness (Hill 1972:288). Service becomes voluntary (Albright \& Mann 1971:242) .

Perhaps the strongest argument that Jesus fulfils the job description of Deuteronomy's king comes during his appearance before Pilate. The Sanhedrin, the political group bringing Jesus

49 See also Matthew 2:6; 9:36; 10:6; and 15:24.

50 This verse combines two concepts from the prophets. Jesus knows himself to be the Son of Man in Daniel 7:13-14 and yet the Suffering Servant of God in Isaiah 53 (especially verses 11 and 12) (Cox 1968:128). Matthew 20:28 arguably shows Jesus' self-image, his concept of himself as Messiah, more so than any other verse in the Gospels, Cox (1968:128) writes.

51 Jesus' disciples are his heirs. They, too, serve. As such, they are to continue the proclamations of Jesus because others need to know God (Stanton, 1982:8). Still others are called to heal, teach, preach; they also are the light of the world. Jesus' disciples for generations to come act as shepherds of the sheep (Stanton 1982 8). 
before Pilate and demanding his execution, acts as the agent of prosecution $^{52}$. The Sanhedrin's charge that Jesus purports to be the Messiah, the King of the Jews, is designed to create anxiety in Pilate (Hill 1972:349). Jesus listens in silence to the charges brought before Pilate from his accusers. Jesus both declines to answer any of them and to assert himself as a possible claimant to Herod's throne (Albright \& Mann 1971:342).

While Jesus stands before the governor ${ }^{53}$, Pilate asks him this loaded question: "Are you the king of the Jews?" (Mt 27:11). Perhaps Pilate's question represents either a flippant mockery of the Jews, a defeated and enslaved nation, or an invitation to commit blasphemy (Filson 1960: 289). Perhaps it implies treason against Caesar (Cox 1968:161). It may indicate his only concern was on whether the man standing before him had broken Roman law (Blomberg 1992:409). During their dialogue, Pilate, a Gentile, unwittingly testifies positively as to Christ's kingship (Blomberg 1992:410).

Jesus replies that yes, he is the king of the Jews (Mt 27:11), but his is not the kind of kingship Pilate mentions and fears. In other words, Jesus' kind of kingship stands outside the domain and authority of Pilate. Jesus poses no threat to Roman rule in Judea. Jesus' answer to Pilate's question, "Yes, it is as you say", means this: "I could truthfully use the title, but you give it a meaning I cannot accept, so I cannot give you a clear Yes" (Filson 1960:289) ${ }^{54}$.

52 The setting is more an arraignment than a formal trial; the passage contains the pattern of question and answer that is typical of an arraignment setting (Hagner 1995:817).

53 Scholars think the hearing and trial before Pilate took place either in the Tower of Antonia (where Pilate presumably stayed during his times in Jerusalem) or in the old palace of Herod (Hill 1972:349).

54 With this qualified yes, Jesus rejects several prevailing models of kingship. Jesus' kingship is not the militaristic option of the Zealots who advocated a Messiah-led revolt against the established Roman order. Neither is Jesus' kingship the pietistic Messiah of the Pharisees who believed the Messiah's kingdom would come slowly but surely within the context of obedience to the Torah. Neither is Jesus' kingship the status quo of compromise and ritualism advocated by the Saduccees. Instead, the kind of kingship Jesus manifests in Matthew is that of a righteous king whose baptism of fire and coming judgment will bring the existing world order to an end (Mt 3:11-12). Yet Jesus as king also is the righteous lord and servant 
Pilate marvels at Jesus' poise and lack of fear. He begins looking for ways to release this unusual man, indeed this regal man, standing before him (Filson 1960:289).

Significantly, Pilate and the magi are gentiles who recognize Jesus as king. Jesus appears consistently in Matthew as a hidden, unrecognised, unacknowledged, and rejected king. Throughout his ministry, he stresses humility and obedience to the Father's will. Yet he does so in a regal way. Throughout his ministry, he acts in an assertive but gracious manner as the one exercising full power and authority as God's representative. While ministering in humility and power, he interprets the law according to the will of God (Hill 1972:65). In this way he fulfils the idea of kingship in Deuteronomy. Deuteronomy's ideal Israelite and king rules with justice and compassion; his rule guarantees righteousness and peace as well as the well-being of the poor and humble (Davidson 1905:123). Jesus in Matthew exemplifies these qualities.

An emphasis for many years in New Testament biblical scholarship has been on Jesus" directives to "tell no man" 55 . These directives largely concerned miraculous healings ${ }^{56}$. Scholars think these commands toward secrecy, dubbed the "Messianic secret," come from Jesus' desire to avoid inflaming popular but mistaken messianic expectations that looked for immediate political deliverance (Hagner 1993:199) ${ }^{57}$. Perhaps this "Messianic secret"

shepherd whom God chooses to bring in a just reign of God. This servant king will bring in God's reign without breaking a bruised reed or quenching a dimly burning wick (Mt 12: 17-21; Is 42:1) (Freeman 1993:287-288).

55 See Matthew 8:4; 9:30; 12:16; 16:20; 17:9; Mark 1:44; 5:43; 7:36; Luke 5:14 (see Guelilch 1989:76; Hagner 1993:199).

56 In commanding those whom he healed to present themselves to a priest, Jesus confirms his compliance with the Torah; cleansing is a priestly prerogative that Jesus did not usurp (Nolland 1989:228).

57 W Wrede (1971 [German original 1901]) offers a different view that has shaped New Testament thinking for more than a century. Wrede believes that the commands to silence reflect the later additions of believers in the early church; the early church, according to his theory, added the injunctions to silence in order to account for how it came to believe in Jesus as Messiah when in fact he had never made such claims or done anything to merit this kind of attention (see Blomberg 1992:139). Moyise (2004) adds that Wrede views the disciples as coming to no such understanding that Jesus was the messiah. 
needs to be reconsidered. Could not Jesus' commands to "tell no man" also stem from a desire not to be recognized yet as Israel's rightful king? Truly, the key to the so-called "Messianic secret" and the secret that Jesus was indeed the kind of earthly king outlined in Deuteronomy is that Jesus did not come as was widely expected - as a conquering Divine Warrior (Ex 15:3). He came as a servant Messiah, trusting his life and will to his Father. The possibility clearly exists that Miller (1990:149) is correct: Deuteronomy's king finds "actuality in Jesus of Nazareth".

\section{Consulted literature}

Allbright, W F, \& Mann, C S 1971. Matthew: Introduction, Translation, and Notes. New York: Doubleday, Garden City (The Anchor Bible Commentary).

Bennett, C 1985. "Temptation-transfiguration: The path between two extremes". The Expository Times 96, 142-143.

Blomberg, C L 1992. Matthew. Nashville: Broadman Press (The New American Commentary Vol 22).

Carter, W 1997. “'Solomon in All his Glory': Intertextuality in Matthew 6:29”. Journal for the Study of the New Testament 65, 3-25.

Charette, B 1992. "To proclaim liberty to the captives: Matt. 11:28-30 in the light of prophetic expectation". New Testament Studies 38, 290-297.

Childs, B S 1985. Old Testament Theology in a Canonical Context. Philadelphia: Fortress Press.

Cox, G E P 1968. The Gospel According to Saint Matthew: Christ the Fulfiller. London: SCM Press (Torch Bible Commentaries).

Craddock, F B 1990. "Testing that never ceases". The Christian Century 107, 211.

Craigie, P C 1983. Psalms 1-50. Dallas: Word Books (Word Biblical Commentary).

Daube, D 1971. "One from among your brethren shall you set as king over you". Journal of Biblical Literature 90, 480-481.

Davidson, A B 1905. sv "Prophets and Prophecy". A Dictionary of the Bible. Vol. IV: Pleroma-Zuzim, 106-127.

Driver, S R 1902. A critical and exegetical commentary on Deuteronomy. Edinburgh: T\&T Clark (The International Critical Commentary).

Filson, F V 1960. A Commentary on the Gospel According to St. Matthew. London: Adam \& Charles Black (Black's New Testament Commentaries).

Fokkelman, J P 1975. Narrative Art in Genesis: Specimens of Stylistic and Structural Analysis. Amsterdam: Van Gorcum, Assen.

Freeman, C W 1993. Matthew 3:13-17. Interpretation 47, 285-289. 
Griffiths, D R 1951. Matthew iii.15. The Expository Times 62, 155-157.

Guelich, R A 1989. Mark 1-8:26. Dallas: Word Books (Word Bible Commentary 34A).

Hagner, D A 1993. Matthew 1-13. Dallas: Word Books (Word Biblical Commentary. 33A).

-, 1995. Matthew 14-28. Dallas: Word Books (Word Biblical Commentary. 33B).

Hamilton, M V 1998. The past as destiny: Historical visions in Sam'al and Judah under Assyrian Hegemony. Harvard Theological Review 91, 215250.

Hamilton, V P 1982. Handbook on the Pentateuch: Genesis, Exodus, Leviticus, Numbers, Deuteronomy. Grand Rapids, MI: Baker.

Harstine, S 2002. Moses as a Character in the Fourth Gospel: A Study of Ancient Reading Techniques. Sheffield: Sheffield Academic Press (JSNTS 229).

Hayes, J H, \& Holladay, C R 1987. Biblical Exegesis: A Beginner's Handbook. London: SCM Press.

Hill, D 1972. The Gospel of Matthew. London: Oliphants (New Century Bible).

Jolley, M A 2000. sv "Fear" in D N Freedman, A C Myers \& A B Beck (eds), Grand Rapids, Michigan: William B. Eerdmans, Eerdmans Dictionary of the Bible, 457.

Jonker, L C 2003. Reflections of King Josiah in Chronicles: Late States of the Josiah Reception in 2 Chr 34f. Gütersloh: Gütersloher Verlagshaus.

Kaiser, W C \& Silva, M 1994. An introduction to biblical hermeneutics: The search for meaning. Grand Rapids, MI: Zondervan.

Kohlenberger III, J R 1993. sv "Fasting”. NIV Compact Nave's Topical Bible, 157.

McVann, M “One of the Prophets: Matthew's testing narrative as a rite of passage". Biblical Theology Bulletin 23, 14-20.

Milikowsky C 1988. “Which Gehenna?” New Testament Studies 34, 238-249.

Miller, P D 1990. Deuteronomy. Louisville, KY: John Knox Press (Interpretation).

Moyise, S 2003-4. Professor of New Testament, Chichester University, Chichester, United Kingdom. Comments made in Pietermaritzburg, South Africa, in April 2003 during a workshop conference, "The Old Testament in the New" and subsequent comments via email.

Nelson, R D 2002. Deuteronomy. Louisville, KY: Westminster John Knox Press (The Old Testament Library).

NIV Study Bible. 1995. $10^{\text {th }}$ ed. General editor, K Barker. Grand Rapids, MI: Zondervan. 
Nolland, J 1989. Luke 1-9:20. Dallas: Word Books (Word Bible Commentary. $35 \mathrm{~A})$.

Pryblyski, B 1974. The Role of Mt. 3:13-41 in the structure and theology of the Gospel of Matthew. Biblical Theology Bulletin 4, 222-235.

Richardson, P 2000. sv "Herod (Family)". Eerdmans Dictionary of the Bible, 579-584.

Rogerson, J W, \& McKay, J W 1977. Psalms 1-50. Cambridge: University Press (Cambridge Bible Commentary).

Sim, D C 1996. Apocalyptic Eschatology in the Gospel of Matthew. In: M E Thrall (ed). Society for New Testament Studies Monograph Series. Cambridge, England: Cambridge University Press.

Smith, G A ND. "Isaiah", In: W R Nicoll (ed), The Expositor's Bible. (Volume 3). New York: George H Doran Company, 615-846.

Sobosan, J G 1974. "Completion of Prophecy: Jesus in Luke 1:32-3". Biblical Theology Bulletin 4, 317-323.

Stanton, G N 1982. "Matthew 11:28-30: Comfortable words?" The Expository Times 94, 3-9.

Taylor, N H 2001. The Temptation of Jesus on the Mountain. Journal of the Society of the New Testament 83, 27-49.

Thompson, J A 1974. Deuteronomy: An Introduction and Commentary. London: Inter-Varsity Press (Tyndale Old Testament Commentaries).

Wrede, W 1971. The Messianic Secret. London: J Clarke (German original, 1901).

US Constitution. http://www.house.gov/Constitution/Constitution.html 